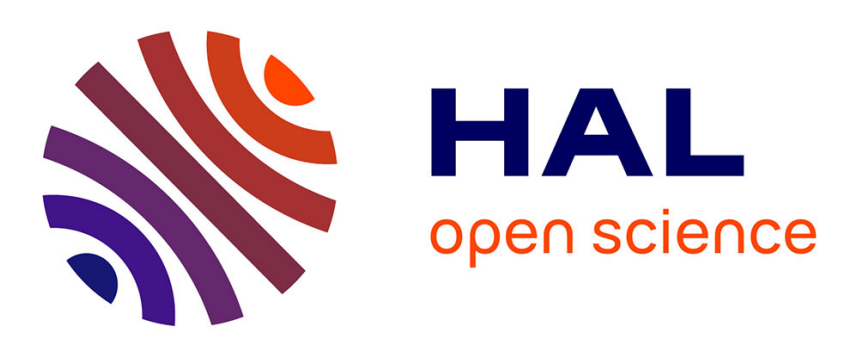

\title{
Comment Objective utilization of data from DSDP Site 380 (Black Sea)
}

Speranta-Maria Popescu, Mihaela Carmen Melinte-Dobrinescu, Jean-Pierre Suc

\section{- To cite this version:}

Speranta-Maria Popescu, Mihaela Carmen Melinte-Dobrinescu, Jean-Pierre Suc. Comment Objective utilization of data from DSDP Site 380 (Black Sea). Terra Nova, 2016, 28 (3), pp.228-229. 10.1111/ter.12209 . hal-01312909

\section{HAL Id: hal-01312909 https://hal.science/hal-01312909}

Submitted on 9 May 2016

HAL is a multi-disciplinary open access archive for the deposit and dissemination of scientific research documents, whether they are published or not. The documents may come from teaching and research institutions in France or abroad, or from public or private research centers.
L'archive ouverte pluridisciplinaire HAL, est destinée au dépôt et à la diffusion de documents scientifiques de niveau recherche, publiés ou non, émanant des établissements d'enseignement et de recherche français ou étrangers, des laboratoires publics ou privés. 


\title{
Comment
}

\section{Objective utilization of data from DSDP Site 380 (Black Sea)}

\author{
Speranta-Maria Popescu ${ }^{1}$, Mihaela Carmen Melinte-Dobrinescu ${ }^{2}$ and Jean-Pierre $\mathrm{Suc}^{3}$ \\ ${ }^{1}$ GeoBioStratData.Consulting, 385 Route du Mas Rillier, 69140, Rillieux la Pape, France \\ ${ }^{2}$ National Institute of marine Geology and Geo-Ecology, 23-25 Dimitrie Onciul Street, 70318 \\ Bucharest, Romania \\ ${ }^{3}$ Sorbonne Universités, UPMC Université Paris 06, CNRS, Institut des Sciences de la Terre \\ Paris, F-75005 Paris, France
}

van Baak et al. provide magnetostratigraphy for DSDP Hole 380A along a $175 \mathrm{~m}$ interval and ${ }^{40} \mathrm{Ar} /{ }^{39} \mathrm{Ar}$ date at $706.8 \mathrm{mbsf}$. The biostratigraphic basis for their interpretation is the first consistent occurrence (FCO) of the dinoflagellate cysts Galeacysta etrusca and Caspidinium rugosum at 841 and $850 \mathrm{mbsf}$, respectively (Groothe et al., 2014), instead of at least 1009.36 mbsf as demonstrated by Suc et al. (2015) (Fig. 1A). Grothe et al. (2014) proposed an age of $6.1 \mathrm{Ma}$ for this event from the Taman Peninsula. We repeat that the placement of this bioevent at $6.1 \mathrm{Ma}$ is significantly lower in the sedimentary succession of Site 380 (Fig. 1A).

van Baak et al. contest the occurrence of calcareous nannofossils in Hole 380A, especially at 840.07 mbsf because they did not record nannofossils in the interval 840-856 mbsf. They write on p. 435: "The supposed presence of the rare biostratigraphic markers T. rugosus and C. acutus... should be associated with other taxa constituting the common component of a typical lower Pliocene nannofossil assemblage". The beginning of this sentence questions our honesty or our expertise, or both, and the end of this sentence implies that we did not record the expected complete nannofossil assemblage.

Our search for nannoplankton was driven by the occurrence of marine dinoflagellate cysts found during a high-resolution study (Popescu, 2006; Fig. 1A). Here, we show in Figure 1B photographs of the recorded nannofossils. Popescu et al. (2010: table 1) published the complete nannoflora, typical of Lower Pliocene (Fig. 1B1).

In Figure 1A, we display all the information available for Site 380 between 1019.85 and 645 mbsf, by depth. We chose depth instead of the time plot of van Baak et al. (2015), because the time plot distorts the curves in a model-driven presentation, the chronology of which is contradicted by our data. Here, the interval 839.30-851.28 mbsf with the high range of surface-water salinity determined by Schrader (1978) agrees with the low percentages of halophytes.

Considering (Fig. 1A):

- the robust data with a wide-scale significance, such as the ${ }^{40} \mathrm{Ar} /{ }^{39} \mathrm{Ar}$ dating at $4.36 \pm$ $0.19 \mathrm{Ma}$, the N1, N2, and N3 normal palaeomagnetic episodes, and the nannofossil markers (Sphenolithus abies and Reticulofenestra pseudoumbilicus at $748.45 \mathrm{mbsf}$, Ceratolithus acutus and Triquetrorhabdulus rugosus at $840.07 \mathrm{mbsf}$ ), and

- the occurrence of the Galeacysta etrusca complex (Popescu et al., 2009) and Caspidinium rugosum at least from $1009.36 \mathrm{mbsf}$ (FCO at $6.1 \mathrm{Ma}$ ),

we consider that the only reliable interpretation is to correlate the interval 864.50-840.00 mbsf with the lowermost Zanclean and, as a consequence, the underlying Pebbly Breccia with the $2^{\text {nd }}$ step of the Messinian Salinity Crisis (Clauzon et al., 1996) (Fig. 1C). The normal episodes N1, N2, and N3 can be, respectively attributed to palaeomagnetic chrons C3n.2n, C3n.3n, and C3n.4n, as proposed by van Baak et al. (2015) or, allowing for the confidence range of the ${ }^{40} \mathrm{Ar} /{ }^{39} \mathrm{Ar}$ dating, respectively to chrons C3n.1n, C3n.2n, C3n.3n, an interpretation not considered by van Baak et al. (2015) (Fig. 1C). 
An important change in the pollen record at $703 \mathrm{mbsf}$, indicating the replacement of forests by open vegetation, has been correlated with the cooling at $3.37 \mathrm{Ma}$ (Fig. 1C), consistent with the record of Sphenolithus abies and Reticulofenestra pseudoumbilicus at $748.45 \mathrm{mbsf}$ (Popescu et al., 2010): the first hypothesis in Figure 1C. This correlation calls into question the immediately underlying ${ }^{40} \mathrm{Ar} /{ }^{39} \mathrm{Ar}$ age of $4.36 \pm 0.19 \mathrm{Ma}$ and would involve correlating the N1, N2, and N3 normal episodes respectively with chrons C2An.3n, C3n.1n, and C3n.2n, a construction that distorts the sedimentation rate (Fig. 1C). As a second hypothesis (Fig. 1C), we can correlate this vegetation change with the cooler MIS Gi22 and Gi20. Accordingly, N1, $\mathrm{N} 2$ and N3 episodes would correspond to chrons C3n.1n, C3n.2n, and C3n.3n respectively. Forthcoming studies should close this matter, particularly in achieving magnetostratigraphy of Site 380 .

\section{References}

van Baak, C.G.C., Radionova, E.P., Golovina, L.A., Raffi, I., Kuiper, K.F., Vasiliev, I. and Krijgsman, W., 2015. Messinian events in the Black Sea. Terra Nova, 27, 433-441.

Clauzon, G., Suc, J.-P., Gautier, F., Berger, A. and Loutre, M.-F., 1996. Alternate interpretation of the Messinian salinity crisis: Controversy resolved? Geology, 24, 4, 363366.

Grothe, A., Sangiorgi, F., Mulders, Y.R., Vasiliev, I., Reichart, G.-J., Brinkhuis, H., Stoica, M. and Krijgsman, W., 2014. Black Sea desiccation during the Messinian Salinity Crisis: Fact or fiction? Geology, 42, 563-566.

Hilgen, F., Kuiper, K., Krijgsman, W., Snel , E. and van der Laan, E., 2007. Astronomical tuning as the basis for high resolution chronostratigraphy: the intricate history of the Messinian Salinity Crisis. Stratigraphy, 4, 231-238.

Hilgen, F.J., Lourens, L.J. and Van Dam, J.A., 2012. The Neogene Period. In: The Geological Time Scale 2012 (F. Gradstein, J. Ogg, M. Schmitz and G. Ogg eds.), 1, 29, 923-978, Elsevier, Amsterdam.

Popescu, S.-M., 2006. Late Miocene and early Pliocene environments in the southwestern Black Sea region from high-resolution palynology of DSDP Site 380A (leg 42B). Palaeogeography, Palaeoclimatology, Palaeoecology, 238, 64-77.

Popescu, S.-M., Dalesme, F., Jouannic, G., Escarguel, G., Head, M.J., Melinte-Dobrinescu, M.C., Sütő-Szentai, M., Bakrac, K., Clauzon, G., Suc, J.-P., 2009. Galeacysta etrusca complex, dinoflagellate cyst marker of Paratethyan influxes into the Mediterranean Sea before and after the peak of the Messinian Salinity Crisis. Palynology, 33, 105-134.

Popescu, S.-M., Biltekin, D., Winter, H., Suc, J.-P., Melinte-Dobrinescu, M.C., Klotz, S., Combourieu-Nebout, N., Rabineau, M., Clauzon, G. and Deaconu, F., 2010. Pliocene and Lower Pleistocene vegetation and climate changes at the European scale: Long pollen records and climatostratigraphy. Quaternary International, 219, 152-167.

Raffi, I., Backman, J., Fornaciari, E., Pälike, H., Rio, D., Lourens, L. and Hilgen, F., 2006. A review of calcareous nannofossil astrobiochronology encompassing the past 25 million years. Quaternary Science Reviews, 25, 3113-3137.

Schrader, H.-J., 1978. Quaternary through Neogene history of the Black Sea, deduced from the paleoecology of diatoms, silicoflagellates, ebridians, and chrysomonads. In: Initial Report of the Deep Sea Drilling Project, Vol. 42, Part 2. (D.A. Ross and Y.P. Neprochnov, eds.), pp. 789-902. U.S. Government Printing Office, Washington.

Shackleton, N.J., Hall, M.A. and Pate, D., 1995. Pliocene stable isotope stratigraphy of Site 846. In: Proceedings of the Ocean Drilling Program, Scientific Results, Vol. 138 (N.G. Pisias, L.A. Mayer, T.R. Janecek, A. Palmer-Julson and T.H. van Andel, eds.), pp. 337-355. U.S. Government Printing Office, Washington. 
Suc, J.-P., Gillet, H., Çağatay, M.N., Popescu, S.-M., Lericolais, G., Armijo, R., MelinteDobrinescu, M.C., Şen, Ş., Clauzon, G., Sakınç, M., Zabcı, C., Ucarkus, G., Meyer, B., Çakir, Z., Karakaş, Ç., Jouannic, G. and Macaleţ, R., 2015. The region of the Strandja Sill (North Turkey) and the Messinian events. Marine and Petroleum Geology, 66, 149-164.

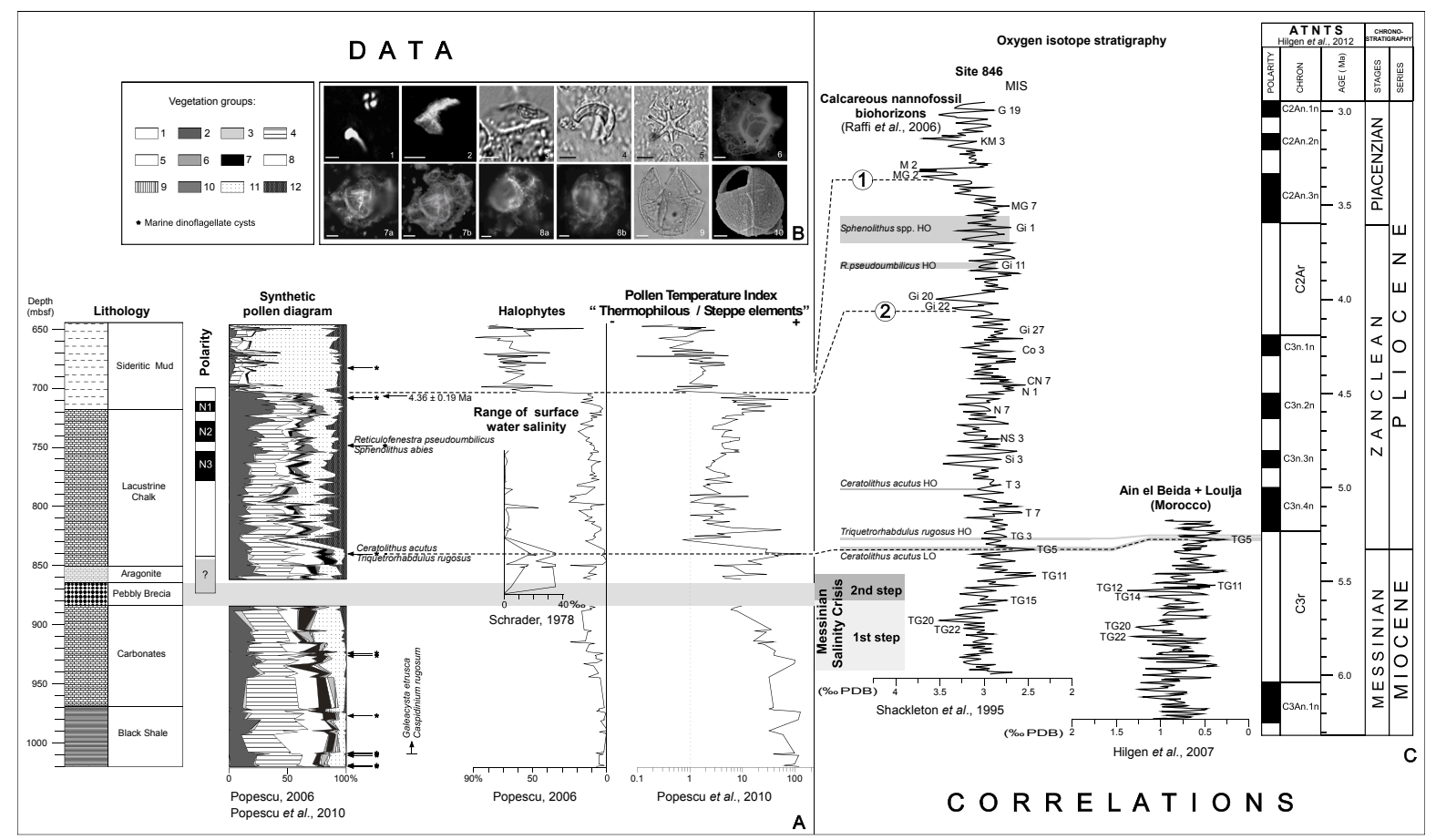

Fig. 1. Chronostratigraphic and environmental data on the lower part of Hole 380A (1019.85-645 mbsf) and proposed correlations.

A, Data presented according to depth. Vegetation groups for the synthetic pollen diagram: 1, Tropical elements; 2, Subtropical elements; 3, Cathaya; 4, Warmtemperate elements; 5, Pinus; 6, Cool-temperate elements; 7, Boreal elements; 8, Non-significant pollen grains; 9, Mediterranean xerophytes; 10, Cupressaceae; 11, Herbs; 12, Steppe elements. For details, see Popescu (2006) and Popescu et al. (2010).

B, Biostratigraphic markers (scale bar $=10 \mu \mathrm{m}$ for Figs. 1, 6-10; scale bar $=7 \mu \mathrm{m}$ for Figs. 2-5):

Calcareous nannofossils:

1, Assemblage with Ceratolithus acutus and Reticulofenestra sp., crossed nicols (840.07 mbsf); 2, Ceratolithus acutus, crossed nicols (840.07 mbsf); 3, Triquetrorhabdulus rugosus, parallel light (840.07 mbsf); 4, Amaurolithus primus, parallel light (840.07 mbsf); 5, Discoaster brouweri, parallel light (840.07 mbsf);

Dinoflagellate cysts:

6-8, Galeacysta etrusca complex (Popescu et al., 2009), fluorescence microscopy:

6, Spiniferites balcanicus (846.14 mbsf); 7a-b, Galeacysta etrusca (1009.36 mbsf);

8a-b, Romanodinium areolatum (1009.36 mbsf);

9-10, Caspidinium rugosum, light microscopy and SEM (1009.36 mbsf).

$\mathrm{C}$, Proposed correlations based on consideration of all the proxies. Hypotheses 1 and 2 concerning the upper part of the interval are discussed in the text.

MIS: Marine isotope stage. LO, Lowest occurrence; HO, Highest occurrence. 